\title{
10-Kültürün metinler yoluyla aktarımı bağlamında Türkçe ders kitaplarında geleneksel çocuk oyunları
}

\section{İbrahim YILDIRIM'}

APA: Yıldırım, İ. (2022). Kültürün metinler yoluyla aktarımı bağlamında Türkçe ders kitaplarında geleneksel çocuk oyunları. RumeliDE Dil ve Edebiyat Araştırmaları Dergisi, (26), 173-184. DOI: 10.29000/rumelide.1073882.

\section{$\ddot{O} \mathbf{z}$}

Bu çalışmanın amacı, ilköğretimin Türkçe ders kitaplarında yer alan metinlerde, önemli bir kültür unsuru olan geleneksel çocuk oyunlarına ne ölçüde yer verildiğinin tespit edilmesidir. Bu amaçla araştırma, tarama çalışması şeklinde düzenlenmiştir. Doküman inceleme yöntemiyle toplanan araştırmanın inceleme nesnelerini, MEB tavsiyeli olarak ilkokul ve ortaokul Türkçe derslerinde okutulan kitaplarındaki metinler oluşturmaktadır. 2016-2017 öğretim yılında okullarda eğitim gereci olarak kullanılan üçüncü, dördüncü ve beşinci sınıf Türkçe ders kitaplarının metinleri incelenmiştir. İnceleme ana metinler ve serbest okuma parçaları ile görseller üzerinden gerçekleşmiştir. Elde edilen veriler nitelik ve nicelik açısından değerlendirilmiştir. Değerlendirme, oyun adı, oyun görseli, oyun tekerlemesi, oyun gereci, oyun içeriği gibi kriterler üzerinden yapılmıştır. İnceleme sonucunda, kitap yazarlarının dil becerilerini öne çıkarmaya çalıştıkları, çocukları milli bir kültür unsurları ile buluşturmayı hedeflemedikleri belirlenmiştir. Yazarlar, metni sadece bir araç olarak kabul etmekte ve metnin çocuğa aktarabileceği mesajları dikkate almamaktadırlar. Metin seçimlerinde oyun çağında olan ve oynayarak mutlu olabilecek 7-12 yaş aralığındaki çocuklara hitap edildiği göz ardı edilmiştir. Bu dikkatsiz ve özensiz yaklaşım neticesinde, çocuğun dünyasına doğrudan ulaşma firsatı kaçırıldığı gibi, metinlerin kültür aktarıcılığı fonksiyonu da değerlendirilememiştir. Yeterince kitap okuma alışkanlığı kazanamamış öğrencilerin dahi, ders kitaplarındaki metinlerini severek okuduğu dikkate alındığında, bu firsatın milli bir değer olan ve teknoloji karşısında sürekli küçülen oyunlar adına bir kayıp olduğu gözlenmiştir. Buna göre Türkçe ders kitaplarında geleneksel çocuk oyunlarına daha özenle yaklaşılabilir, genel “oyun” sözü yerine detay verilebilir, görseller hazırlanırken oyunlar daha net bir biçimde yansıtılabilir. Bu şekilde birazcık dikkat ve çaba ile önemli bir kültür unsurunun var olmasına destek sağlanabilir.

Anahtar kelimeler: Türkçe eğitimi, kültür aktarımı, oyun

\section{Transfer through cultural texts: The place of traditional childrens games in primary school Turkish books}

\begin{abstract}
The aim of this study is to determine the extent to which traditional children's play, which are an important cultural element, are included in the texts of Turkish primary school textbooks. For this purpose, the third, fourth and fifth grade Turkish textbooks accepted by the Ministry of National Education in 2016-2017 and studied in the schools were examined. The examination was based on main texts and free reading pieces and visuals. The obtained data were evaluated in terms of quality and quantity.The evaluation was made on criteria such as game name, game image, game rhyme,
\end{abstract}

Doktora, Bakü Devlet Üniversitesi Türkoloji Bölümü (Bakü, Azerbaycan), ibrahimyildirim2023@gmail.com, ORCID ID: 0000-0002-5072-255X [Araştırma makalesi, Makale kayıt tarihi: 10.01.2022-kabul tarihi: 20.02.2022; DOI: 10.2900o/rumelide.1073882]

RumeliDE Dil ve Edebiyat Araştırmaları Dergisi Osmană̆a Mahallesi, Mürver Çiçeği Sokak, No:14/8 Kadıköy - ISTANBUL / TÜRKIYE 34714 e-posta: editor@rumelide.com tel: +90 $5057958124,+902167730616$
Address

RumeliDE Journal of Language and Literature Studies

Osmanağa Mahallesi, Mürver Çiçeği Sokak, No:14/8

Kadıköy - ISTANBUL / TURKEY 34714

e-mail: editor@rumelide.com,

phone: +90 5057958124, +90 2167730616 
game equipment. It seems that book authors have been trying to create "activity" richness rather than equipping children with a national culture, and to give them the benefits that the program obligates. The text is regarded only as a means, and the content of the text is not sufficiently considered. It has been ignored that it is addressed to children between the ages of 7-12 who are in the age of play and can only be happy by playing. In this way, the opportunity to directly reach the child's world has not been used well, and the text has come to ignore the cultural transfer function. Considering that even the students who have not gained the habit of reading enough books read the texts in the textbooks fondly, it has been observed that this opportunity is a loss for the games. At the end of the research, by looking at the results, suggestions were made to the book authors to raise awareness for the traditional children's games to be included in the textbooks more

Keywords: Turkish Education, Cultural Transfer, Play

\section{Giriş}

Eğitim-öğretimde en önemli kaynaklardan biri, kazanımların gerçekleştirilmesinde en fonksiyonel materyal olan ders kitaplarıdır. Ders kitaplarının içerik olarak önemli kısmını metinler veya okuma parçaları oluşturmaktadır. Türkçe ders kitaplarında yer alan metinler, Türkçe dersinin amaçlarının gerçekleşmesinde önemli bir görev üstlenmektedir. Bu anlamda çocuğun zihin, dil ve sosyal gelişimine uygun hazırlanmış metinler oldukça önemlidir.

Türkçe derslerinde ana dile ilişkin temel becerilerin kazandırılması öncelikli hedeftir. Daha sonra metinler yoluyla öğrencinin kültürel değerleri tanıması ve aktif bir uygulayıcısı olması amaçlanır. Metinler, öğrencilerin dil ve zihin gelişimlerine katkıda bulunmanın yanı sıra içeriklerinde taşıdıkları mesajlarla, kültürel çerçevenin oluşmasında da önemli rol üstlenmişlerdir. Dil bir toplumun anlaşma vasıtası olduğu gibi aynı zamanda bir kültür taşıyıcısı ve kültür aktarıcısıdır (Özbay, 2002: 115). Araştırmacılar, geçmiş yüzyllardan günümüze kadar ulaşmış Türkçe metinleri incelediklerinde, dönemin örf, gelenek, inançlar, yeme- içme kültürü, sosyal yapı, değer verilen kavramlar ve genel manada kültür değerleri hakkında etraflı bilgiye ulaşlabilmektedir. Kültürü dilin aynası gibi gören Aksan (1975: 430) bu konuda görüşleri şu şekilde ifade etmektedir: "Bir dilin söz varlığının (kelime hazinesinin) incelenmesi, o dili konuşan toplumun maddi ve manevi kültürü üzerinde bize en inandırıcı tanıkları getirir. O ulusun yasayış biçimi, inançları, gelenekleri, toplumda önem verilen kavramlar ve tarih boyunca ortaya çlkan çeşitli değişmeler, giderek o toplumun birçok nitelikleri, söz varlığında kendini belli eder."

Ders kitaplarında yer alacak metin türlerinin ve metinlerde dikkat edilmesi gereken özelliklerin neler olduğu, hangi temaların işlenmesi gerektiği, uzamanlar tarafından titizlikle hazırlanan MEB Türkçe Öğretim Programında (2005) belirtilmiştir. Program incelendiğinde insani, ahlaki, milli, manevi ve kültürel değerlerin Türk milletinin bireylerine aktarılmasının hedeflendiği görülmektedir. İlk ve orta okulda öğrenim gören öğrencilerinin yaş aralı̆̆ı $7-15$ ’tir. Bu dönem, çocuklara birtakım kültür değerlerini tanıtmak ve bu değerlerin içselleştirmesini sağlamak için en ideal bir dönemdir. Bu yaş dönemi çocuklarının en önemli özelliğinin, Piaget’in ortaya koyduğu bilişsel gelişim dönemleri ve özellikleri dikkate alındığında, "değer ve inanç sisteminin yapılandırıldığı" (Demircan 2006: 69) bir dönem olmasıdır.

Çocuğun, toplumun diğer üyeleri ile kültürel bir paydada buluşabilmesi için önem arz eden ders kitaplarının hazırlanmasına aynı ehemmiyetin verilmediği görülmektedir. Ders kitabı yazarlığı diye bir

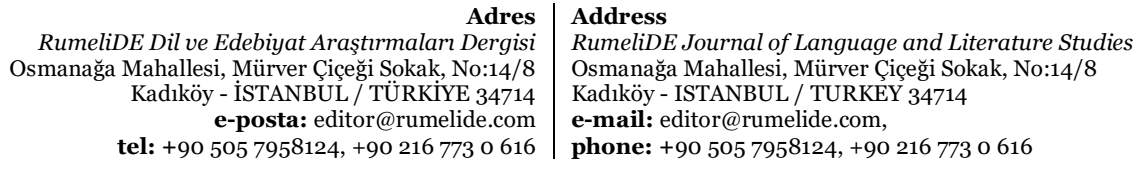


meslek olmadı $\breve{g} ı$ için, farklı becerilere sahip kişiler bu alanda iddialarda bulunabilmektedir. Ders kitabı yazarlı̆̆ı genellikle hemen her öğretmen veya daha genel ifade ile eğitim sektöründe yer alan ve cesareti olan kişilerce yapılabilecek bir iş olarak kabul edilmektedir. Oysa, bir kitabın metinlerini yazarken, öğrencilerin söz varlığına katkı sağlama, kazanımlarının ölçme ve değerlendirmesini sağlıklı olarak yapabilme, öğrenciyi aktif hale getirme, dil becerilerinin gelişimine katkı sağlama, dil bilgisi kazanımlarını geliştirme, kültürel zenginliği keşfettirme gibi çeşitli yetkinliklerin dikkate alınması ve dönemsel psikolojik özelliklerin biliniyor olması gerekmektedir.

1-5. sınıf Türkçe dersi ders programında (MEB, 2005: 180-182) ders kitabını oluşturan tema ve metinler hakkında şu bilgilere yer verilmektedir: 2005 yll öğretim programında tematik yaklaşım gereği, 1-5. sınıfların Türkçe dersinde, bir eğitim-öğretim yılı içerisinde ele alınacak tema sayısı sekiz olarak belirlenip, bu temaların dört tanesi zorunlu, dört tanesi seçmeli olarak tespit edilmiştir. Her temada üç farklı türden; öyküleyici metin, bilgilendirici metin ve şiir olmak üzere beş metin işlenmesi ve bu metinlerden dördü ders kitabında, birisi de dinleme metni olarak öğretmen kılavuzunda yer alması gerektiği ifade edilmektedir. Ayrıca programa göre temalar her sınıf düzeyinde farklı içerikte ele alınmalıdır. Her yazardan en fazla üç metin seçilmelidir. Seçilen metinlerde sadeleştirme, kısaltma ve düzenleme yapılabilir. Metin seçiminde kazanımların gerçekleştirilmesi göz önüne alınarak hareket edilmelidir.

6-8. sınıf Türkçe ders programında ise ders kitabını oluşturan tema ve metinler hakkında şu bilgilere yer verilmektedir: Her sınıf seviyesinde, biri zorunlu Atatürkçülük teması olmak üzere altı ana tema ele alınır. Altıncı sınıfta "sevgi”, yedinci sinıfta "milli kültür", sekizinci sınıfta "toplum hayatı" zorunlu ana temalardır. Ana temalar altında belirtilen alt temalar zenginleştirilebilir. Metinler, dersin amaçları ile kazanımlarını gerçekleştirecek nitelikte olmalı, öğrencilerin ilgi alanlarına ve seviyesine uygun olmalı, dil, anlatım ve içerik acısından türünün güzel örneklerinden seçilmeli, öğrencilerin duygu ve düşünce dünyasını zenginleştirmek amacına yönelik olarak farklı yazar ve şairlerden seçilmeli, yazar ve şairlerin yalnızca edebi yönlerini ön plana çıkarmalı, öğrenciye okuma sevgisi ve alışkanlığı kazandıracak nitelikte olmalıdır. Düzenleme sırasında metne cümle ya da paragraf düzeyinde ekleme yapılamaz (MEB, 2006:56)

Yazar ve öğretmenlere ana çerçeveyi belirleyerek rehber olmayı amaçlayan bu açılamalar, ders kitaplarındaki metinlerin nasıl hazırlanacağı, hangi kelime hazinesine göre metinlerin oluşturulacağı, milli kültür konusunda gösterilmesi gereken hassasiyeti ana çizgilerle ifade etmektedir. Milli Eğitim Bakanlığı, ders kitaplarını ya kendisi kuruduğu komisyonlara yazdırmakta ya da farklı yayınevlerine hazırlatmaktadır. Bakanlık itap hazırlama süreçlerine dair, metin türlerinin ve metinlerin seçiminde belirlediği ölçüleri ifade edip, genel çerçeveyi yazarlara aktarmakta; ders kitaplarındaki metinlerin, metin türlerin secimi ve içeriklerinin belirlenmesini ise doğal olarak yazarların veya yayınevlerin inisiyatifine bırakılmaktadır. Yine bu metinlerde milli kültür unsurlarına ne ölçüde yer verileceği, hangi ünitede hangi metnin kullanılacağı, kitabın görselleri (fotoğraf, resim, çizimler) gibi hususlar, yazarın veya tasarımcının hayal gücüne, milli değerlere verdiği ferdi öneme ve yeteneklerine bırakılmaktadır.

Türkçe dersi hem beceri hem de bilgi dersidir. Dört ana öğrenme alanı bulunmaktadır. Bunlar dinleme, okuma, konuşma ve yazmadır. Türkçe eğitiminin genel amacı, öğrencilerin okuyup dinlediklerini anlamaları ve düşündüklerini söz ve yazı ile anlatabilmeleridir. Başka bir ifadeyle öğrencilerin anlama ve anlatma becerilerin metin çözümlenmesi ve değerlendirilmesiyle geliştirilmesidir. Bu yönüyle metin türlerin secimi ve hazırlanması çok önemlidir. Bu metinler aynı zamanda çocuğun kültür coğrafyasının da sınırlarını oluşturmaktadır. Çocuğun kültürel kimliğe bürünmesi, onun ait kültürün değerlerini

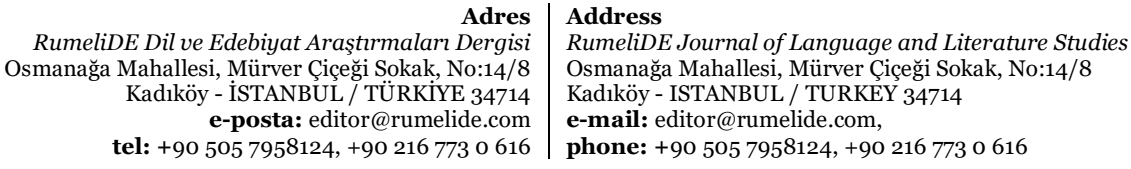


sezmesinde çok büyük öneme haizdir. Sever (2006:11)'e göre Türkçe öğretiminde, öğrencilerin ilgi, ihtiyaç ve dil aşamalarına uygun olarak seçilen nitelikli metinler, onların duygu ve düşünce eğitiminde önemli sorumluluklar üstlenir. "İlgi” terimi esas alındığında ve mesele "çocuk" ise elbette "oyun" bu metinlerin seçiminde göz ardı edilmemesi gereken bir alan olarak karşımıza çıkmaktadır.

Genel olarak metin türleri şunlardır: Özgeçmiş, mektup, telgraf, davetiye, dilekçe, ilan, mülakat, rapor, röportaj, tutanak, haber metinleri, makale, köşe yazısı, deneme, portre, söyleşi, eleştiri, inceleme yazısı, anı, günlük, gezi yazısı, şiir, roman, öykü, destan, efsane, masal, fabl, tiyatro, senaryo, biyografi, otobiyografi.

Çocuk edebiyatı ürünleri olarak sayılan metin türleri ise şunlardır: Masal, fabl, destan, efsane, öykü, roman, biyografi, anı, gezi yazısı, doğa ve fen olaylarını anlatan eserler, şiir ve tekerlemelerdir (Oğuzkan, 2000).

Türkçe dersi ders programında metin türlerinin dağılımı neye göre ve nasıl olmaktadır? Ders kitabının hazırlanmasında cevaplanması gereken önemli sorulardan biri de, "Yukarıda ifade olunan türlerden hangileri ders kitabında yer almalıdır?” sorusudur.

1-5. sınıf Türkçe dersi ders programında her temada üç farklı türden; öyküleyici metin, bilgilendirici metin ve şiirden olmak üzere beş metin işlenmesi gerektiği söylenmektedir. (MEB, 2006:57). Programda neden bu türlerin seçildiği hakkında açıklama yapılmamakla beraber, genel kabul gören iki alandan, düz yazı (bilgi verici - hikaye) ve manzum eser şeklinde, örneklemeler tercih edilmiştir.

İlk çocukluk döneminden itibaren çocukların zihin, dil, kişilik ve sosyal gelişiminde çocuk kitaplarının önemli bir görevi bulunmaktadır. Sever (2005:182)'e göre ana dili öğretimi, ilk öğretimin ilk yllından başlayarak daha çok seviyeye uygun edebi metinlerle (masal, şiir, hikaye vb.) gerçekleştirilir. Edebi metinler, didaktik metinler gibi, öğüt vermez. Çocuklara hayat ve insan gerçekliğinin sanatçı duyarlılığı ile kurgulanmış örneklerini sunar. Bu örneklerde ana dilinin yaratıcı gücü, anlatım inceliği ve kuralları, çocuk gerçekliğini kuşatan bir anlayışla sergilenir. Yine Sever (2003:3)'e göre edebiyat bize sanatçı duyarlılı̆̆ı ile kurgulanmış bir yaşam sunar. Hayatımıza yeni anlamlar katar. İnsan ve hayat gerçekliğini sanatçı duyarlı̆̆ ile kavramamıza, bu gerçekliğe sanatçının penceresinden bakmamıza imkan sağlar.

İlkokul Türkçe ders kitaplarında olaya dayalı veya öyküleyici metin türlerinin bilgilendirici metin türlerinden fazla kullanılması, ilgi uyandırma açısından ve soyut düşünme kabiliyetinin zayıflı̆̆ından dolayı, daha yerinde bir tercih olacaktır. Öyküleyici metin türlerinden (masal, fabl, hikaye, efsane, destan, roman, tiyatro, anı, gezi yazısı) masal, fabl, hikaye, anı ve gezi yazısı metin türlerini kullanmak çocukların için daha etkili, zevkli ve heyecanlıdır. Cemiloğlu'na göre gelişim psikolojisi verileri çocuğun zihin gelişiminde soyut düşünmenin on bir yaş civarında başladığını göstermektedir. (2004:29-71)

Türkçe ders programa göre (2005) hazırlanmış 1-8 sınıf Türkçe dersi ders kitaplarındaki metin türlerinin (tasnif edilmiş ve ayrı ayrı metin türleri) dağılımı sınıflara göre aşağıdaki tablolarda gösterilmiştir.

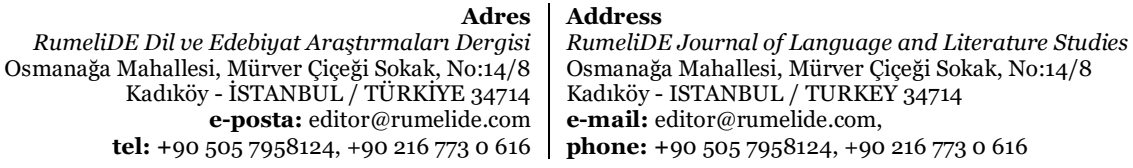




$\begin{array}{lllllllll}\text { Sinıflar } & 1 . \text { sinıf } & \text { 2. sinıf } & 3 . \text { sinıf } & 4 \text {. sinıf } & 5 . \text { sinıf } & \text { 6. sinıf } & \text { 7. sinıf } & 8 . \text { sinıf } \\ \text { Toplam Metin } & 36 & 40 & 40 & 40 & 40 & 24 & 24 & 30 \\ \text { Şiir } & 10 & 14 & 14 & 8 & 10 & 4 & 3 & 7 \\ \text { Öyküleyici metin } & 18 & 15 & 17 & 13 & 14 & 12 & 8 & 9 \\ \text { Bilgilendirici metin } & 8 & 11 & 9 & 19 & 16 & 8 & 13 & 14\end{array}$

Tablo 1. 1. ve 8. sınıf Türkçe ders kitaplarındaki tasnif edilmiş metin türlerinin dağılımı

Türkçe ders kitaplarında yer alan metin türleri ve metin sayıları yukarıda belirtilmiştir. Kitaplarda yer alan metinlerin nitelik ve nicelikleri bu araştırmanın konusu olmadığı için üzerinde yorum yapılmayacaktır. Lakin görüldüğü gibi öyküleyici metinler ve şiir gibi, estetik zevk ve alışkanlık kazandırma imkanı olan metinler üst sınıflarda azalarak, yerini bilgilendirici metinlere bırakmaktadır.

\section{Araştırmanın amacı}

Türkçe ders kitaplarında yer alan metinlerde bu çalışmanın esasını oluşturan şu sorulara cevap aranacaktır:

a) Geleneksel çocuk oyunları (oyun adı, oyun içeriği, oyun gereci veya terimi olarak) ne oranda yer bulabilmiştir?

b) Oyun tekerlemelerine yer verilmiş midir? Verildiyse bunlar nelerdir?

c) Metinlerin görsellerinde çocuk oyunları kullanılmış mıdır?

Değerlendirme MEB tarafından ders kitabı olarak basılan yahut özel yayınevleri tarafından basılan ve ders kitabı olarak okutulabileceği kabul edilen kitaplar üzerinden yapılmıştır. Kitaplarla ilgili künye bilgileri ayrıntılı olarak verilmiştir. Çocuk gelişimine esasla, oyunların aktif olarak oynandığı dokuz ve on bir yaş aralığına tekabül eden 3. sınıf, 4, sınıf 5. sınıf ders kitapları incelenmiştir.

\section{Sınıf Türkçe Ders Kitabı Değerlendirilmesi}

Yorumların yan tarafında verilmiş olan görseller, ilgili ders kitabında, yazar tarafından metnin yer aldığı sayfaya yerleştirilen görsellerdir.

Kitap künyesi: Kitap, Milli Eğitim Bakanlığı Talim ve Terbiye Kurulunun 25.07.2016 gün ve 7873929 sayılı yazısı ile eğitim aracı olarak kabul edilmiş ve 16.08.2016 tarihinde 1.744.873 adet basılmıştır.

Yazarlar: Nagihan Tetik - Nevin Zorlu - Hilal Türker - Zeynep Polat

Editörler: Doç. Dr. Ozay Karadağ - Doç. Dr. Nermin Yazici

Görsel Tasarım: Batuhan Özer - Ayşe Şenay Özdamar - Tunç Karadă̆

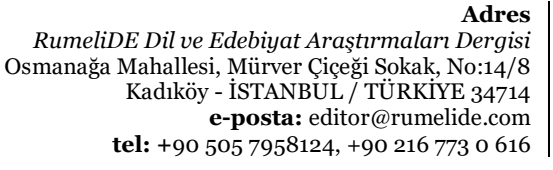

Adres 8

Address

RumeliDE Journal of Language and Literature Studies

Osmanağa Mahallesi, Mürver Çiçeği Sokak, No:14/8

e-mail: editor@rumelide.com,

phone: +90 505 7958124, +90 2167730616 


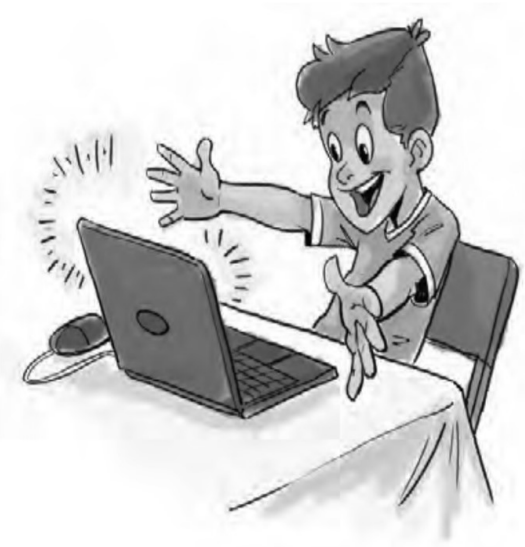

Ders kitabında sekiz ünite bulunmakta olup, dördüncü ünite "Milli Kültürümüz" ünitesi ve yedinci ünite "Sağlık, Spor ve Oyun” ünitesi kültürel unsurların doğrudan verilebileceği üniteler olarak görülmektedir. Dördüncü ünitede milli kültürümüz teması etrafinda "komşuluk, kilim, Nasrettin Hoca ve atasözlerini” ihtiva eden metinler kullanılmıştır. Yedinci ünite spor ve oyun teması işlenirken geleneksel oyunlardan bahsedilmemiş ve sadece bilgisayar oyunları ele alınmıștır. Ünitede ilk metin olarak "oyun tasarlama” başlığıyla bilgisayar oyunlarının nasıl tasarlandığını anlatan bir metin tercih etmiştir. Diğer üç metin de yine bilgisayar oyunları çerçevesinde şekillendirilmiştir. Sadece ünitenin kapağında halat çeken 4 çocuk resmi yer almıştır.

Bu üniteler de dahil olmak üzere kitabın hiçbir metninde geleneksel oyunlara dair, oyun adı, oyun terimi, oynayan çocuk resmi veya fotoğrafı yer almamaktadır.

\section{Sınıf Türkçe ders kitabı değerlendirilmesi}

Millî Eğitim Bakanlığı Talim ve Terbiye Kurulu Başkanlığının 4 15.10.2012 tarih ve 191 sayılı kararı ile 2013-2014 öğretim yılından başlayarak 5 (beş) yıl süreyle ders kitabı olarak kabul edilmiştir.

Sf. 9 : Bebek (Adalet Ağaoğlu)

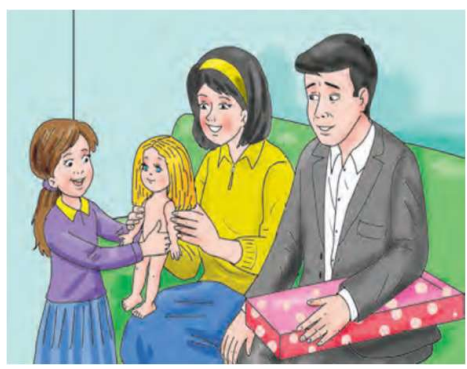

Sf. 14: Rüzgarı Yakala (Aslı Zülal)

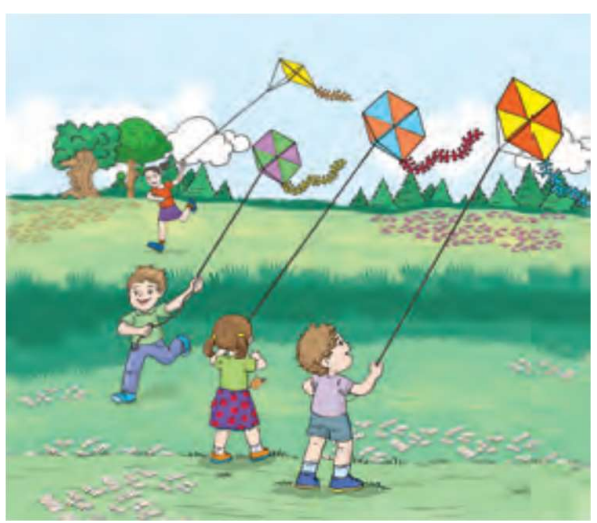

Türk edebiyatının önemli yazarlarından Adalet Ağaoğlu'nun anı türünde kalem aldığı yazı oyuncak bir bebek etrafında şekillenmektedir. Daha çok geleneklerin ve bir kız çocuğunun oyuncak bebeğine duyduğu sevgiyi anlatan başarılı çalışma içerik olarak ve seviye olarak son derece yerindedir.
Uçurtma hakkında ayrıntılı bir bilgi verilmiş ve uçurtmanın nasıl yapılacağı anlatılmıştır. Uçurtma uçurmayı özendirici bir üslupla yazılmış başarılı bir metindir.

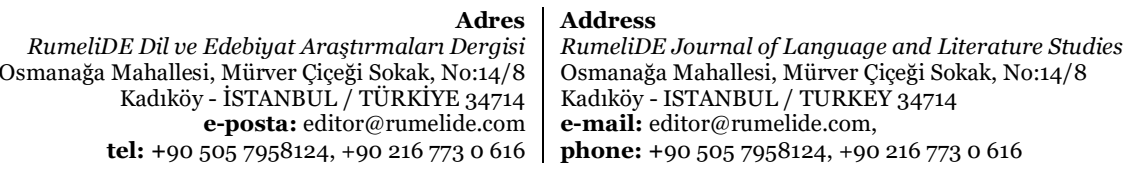

RumeliDE Dil ve Edebiyat Araşturmaları Dergis tel: +90 $5057958124,+902167730616$ 


\section{Sf. 16: Oyun ve Arkadaşlık (Serbest Okuma)}

Bu parçada yazar oyun ve arkadaşlık kavramlarını, paylaşma ve birlik çerçevesinde ele almıştır. Metinde modern oyun gereçlerinden olan "kaykay" ile ilgili şöyle bir cümle kurulmuştur: "Ertesi gün, kolunun altına kaykayını sıkıştıran Çetin, anneannesinin sözlerini düşünerek asansöre bindi.”

\section{Sf. 44: Hayal Çocuk - Niyazi Birinci (Serbest Okuma )}

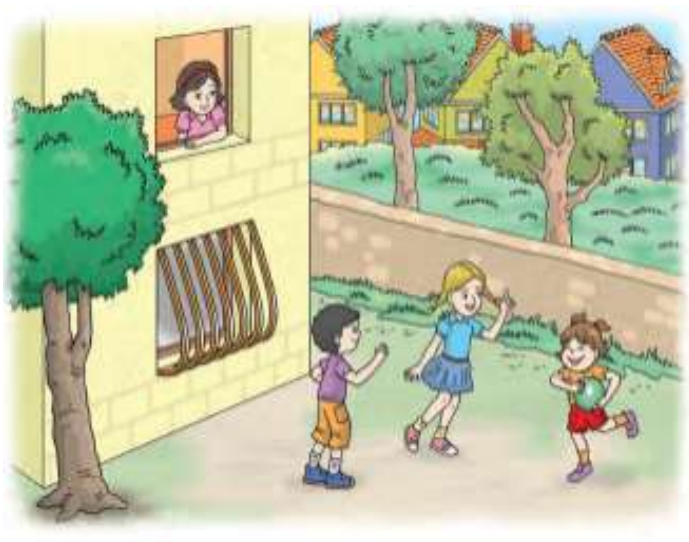

Bedensel engeli nedeniyle bahçeye inemeyen ve sadece uzaktan oyun oynayan çocukları izlemek zorunda kalan bir kız çocuğunun bakışı ile ele alınan metnin görselinde "bahçede top oynayan üç çocuk" resmedilmiştir.

Oyunun ne olduğuna dair bir bilgi yoktur. Bir kız çocuğunun elinde top bulunmaktadır.

\section{Sf. 70 : Bayram Anıları / Zeynep Cemali (Serbest Okuma Parçası)}

$\mathrm{Bu}$ metinde anlatıcı, eski bayram geleneklerini anlatır ve sohbet sırasında geçmiş zaman oyunlarına atıfta bulunur. Konuşmasında patlayıcı bir oyuncak olan "mantar"dan söz eder. "Bayram yerine o götürürdü beni. Önce mantar alıp patlatırdık. Çukurbostan, mantar sesinden geçilmezdi.”

\section{Sf. 74 : Sevgi Güneşi Mevlana (Serbest Okuma Parçası)}

Yine diğer bir metinde yazar bir firsatı değerlendirmeyerek, detay vermeden, genel olarak sadece "oyun" terimini kullanmıştır. Bu metinde, çocuğun dünyasında karşılık bulacak bir oyundan veya oyuncaktan bahsetmek mümkün iken tercih edilmemiştir. "Bu sırada oyun oynamakta olan bir çocuk uzaktan Mevlana'ya oyununu bitirene kadar beklemesini söyledi. Mevlana, çocuğu oyunu bitinceye kadar bekledi. Çocuk, oyunu bitince koşa koşa Mevlana’nın yanına geldi.”

\section{Sınıf Türkçe ders kitabının değerlendirilmesi}

Kitap künyesi: Kitap, Milli Eğitim Bakanlı̆̆ Talim ve Terbiye Kurulunun 12.06.2012 gün ve 65 sayılı kurul kararı ile 2013-2014 öğretim yılından itibaren 5 yll süreyle ders kitabı olarak kabul edilmiştir.

Yazar: Gülşen Erdem (Kartopu Yayıncıllk)

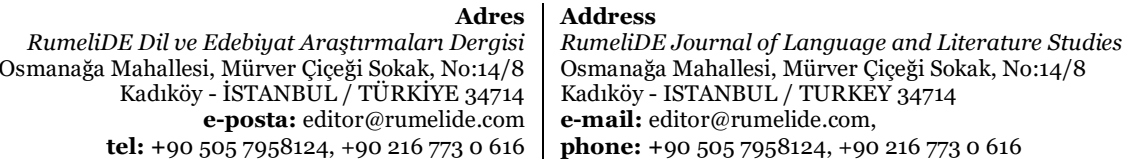




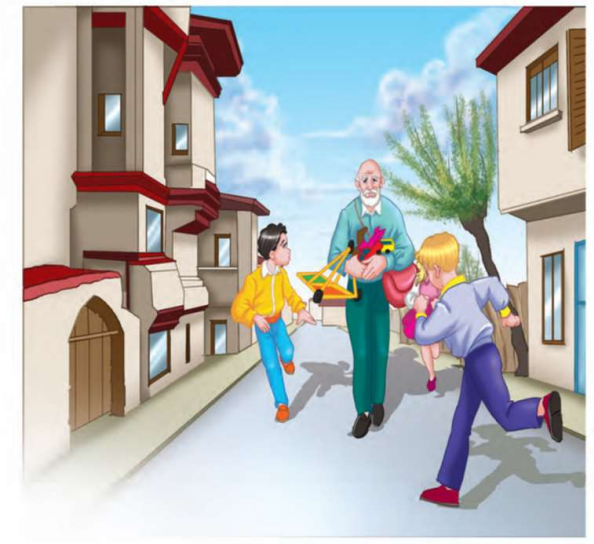

Bir masal formatında yazılan metinde oyuncak satarak geçimini sağlayan yaşlı biri ile bir çocuğun diyalogu verilmektedir. Metinde çeşitli oyuncak isimleri geçmektedir: "Bir zamanlar küçük bir şehirde bir oyuncakçı yaşardı. Bembeyaz sakalı pamuk gibiydi. Oyuncak dükkânı açacak kadar parası yoktu. Koluna taktığı sepetinde çeşit çeşit oyuncaklar bulundururdu. Bebekleri, arabaları, bilyeleri, çemberleri vardı.”

Sf. 172: Etkinlik : Oyunların adlarını yazar mısınız? Bu etkinlikte yazar üç görsel vermiş ve öğrencilerden bu oyunların adlarını yazmalarını istemiştir. Yerinde planlamış, isabetli bir etkinlik olmuştur. Görsellerde Körebe, Birdirbir ve İp Atlama gibi geleneksel ve halen günümüzde var olan oyunların adlarının sorulması yerinde ve duyarlı bir yaklaşım olmuştur.
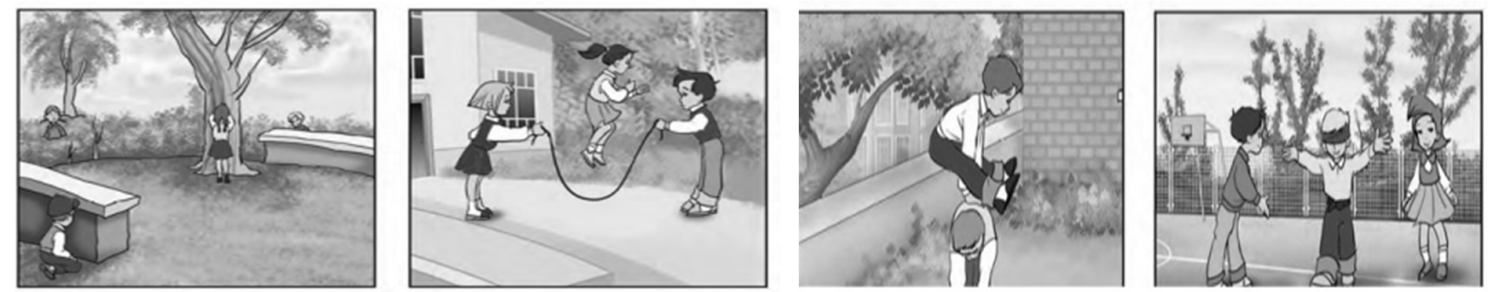

Sf. 174 : Etkinlik: Bir ağaca gözlerini kapatan bir çocuk resmi verilerek, öğrencilerden saklambaç oyununu anlatmaları istenmiştir.

Kitapta oyun veya oyuncakla ilgili başka bir unsura rastlanmamıştır.

\section{Bulgular ve tartışma}

Küreselleşmenin ve medyanın çocuklar ve gençler üzerindeki etkisi arttıkça, kültürel değerler erimekte, yok olmaktadır. Kültürel değerlerin aktarılması, diğer derslerin yanında özellikle Türkçe derslerinde kullanılan metinler aracılı̆̆ıla daha olasıdır. Metinler, bir yandan kültürel değerleri koruyup, gelecek nesillere aktaran bir işlev üstlenirken, diğer yandan aynı değerleri okuyucusuna kazandıran bir sorumluluk yüklenmiştir. Geleneksel çocuk oyunları son yllarda gittikçe eriyen, unutulmaya başlayan kültürel değerlerden biridir. Modern hayat bu oyunları kırsala ait olarak kabul etmiş ve bünyesine katmamıştır. Çocuğun gelişimine yaptığı olumlu katkıların yanında yüzlerce yıllık geçmişi olan oyunlar, bu oyunları oynayabilecek yaşta bulunan ilköğretim çocukları tarafından bilinmemektedir. Bu elbette sadece yazara yüklenecek bir sorumluluk değildir. Değişen sosyal ve kültürel yapı, teknoloji, güvenlik, şehirleşme gibi genel durumlar hayat tarzını değiştirmiştir. Çocukların geleneksel oyunlardan kopuşu bir geleneğin yok olması adına üzücü olmakla birlikte, asıl sorun oyun oynayarak sosyal ve ruhsal gelişimini tamamlayamayan çocukların yaşadıkları ve yaşayacaklarıdır. Ders kitaplarının bu kültürel eriyişte bir kalkan görevi üstlenmesi mümkündür. Oynayan çocuk, mutlu çocuktur. Bu nedenle

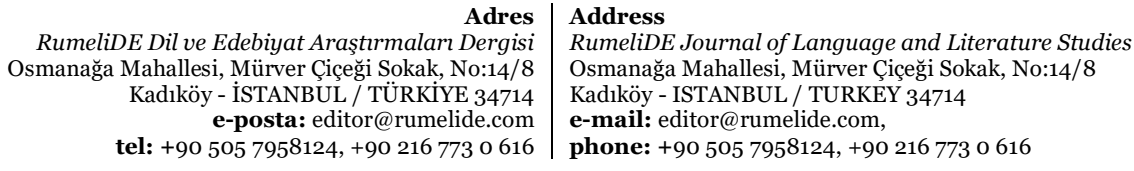


yazarların ders kitaplarında Bakanlığın belirlemiş olduğu ölçütlere göre çalışma yapması, metin seçimlerinde kültürü aktarma işlevini yerine getirmesi beklenmektedir. Bu bağlamda çocuk oyunlarının, önemli bir kültür unsuru olarak, her sınıf düzeyinde Türkçe kitaplarında yer alması, geleneğin yaşatılmasına katkı sağlayacaktır.

Bu araştırma üçüncü, dördüncü ve beşinci sınıf Türkçe ders kitaplarındaki metinlerde çocuk oyunlarına ne oranda yer verildiğini belirlemek amacıyla yapılmıştır. Elde edilen veriler sayısallaştırılarak sunulmuştur. Türkçe ders kitaplarındaki metinlerin, nitel olarak doküman analiziyle ve birebir aktarmalarla incelenmiştir. Bulgular, metin yazarlarının genel olarak milli unsurları sunma çabasında olmadıkları; özel alanda ise "geleneksel oyun" konusunda planlı bir yaklaşım izlememiş̧ olduklarını göstermektedir. Özellikle ders kitaplarının görsellerinde görülen yetersizlikler ve özensizlik şaşırtıcı boyuttadır. Üçüncü, dördüncü ve beşinci sınıf Türkçe ders kitaplarında metinler incelendiğinde;

1. Ders kitaplarında genel olarak milli kültürel unsurların, bu çerçevede de geleneksel oyunların belli bir plan dahilinde verilmesinin düşünülmediği,

2. Tekerleme veya sayışmalara dair bir atıfta bulunulmadığı; hiç olmazsa şiir temalı üniteler bünyesinde tekerlemelere yer verilebilecekken bunun düşünülmediği,

3. Çocuğun hayal ve duygu gücünü arttıran masalın bütün sınıflarda bir veya iki defa kullanıldığı ama bu masalların da diğer türlere göre dağılımında sayıca az olduğu; ayrıca popüler kültürün tesirinde kalınarak Türk masallarının tercih edilmediği belirlenmiştir.

4. Beşinci sınıf Türkçe ders kitabında sekiz ünite bulunmaktadır. Bu üniteler geleneksel oyunlar açısından incelendiğinde şu tespitleri yapmak mümkündür:

- Dördüncü ünite “Milli Kültürümüz” ünitesi; yedinci ünite “Sağlık, Spor ve Oyun” ünitesi kültürel unsurların doğrudan verilebileceği üniteler olmasına rağmen, kitap yazarları oyun sözünü, içi boş ve umumi bir kavram olarak ele almışlar ve altın fırsatı layıkıyla işlememişlerdir.

- Dördüncü ünitede milli kültür kapsamında verilen metinler isabetli olmuş ve milli değerler ile öğrenciler tanıştırılmıştır. "Nasrettin Hoca, komşuluk, kilim ve atasözlerini” ihtiva eden bu metinler başarılıdır.

- Yedinci ünitede ise kitap yazarı oyun denince sadece bilgisayar oyunlarını anlamaktadır. Ünitenin ilk metin olarak "oyun tasarlama” başlı̆̆ıyla bilgisayar oyunlarının nasıl tasarlandığını anlatan bir metin tercih edilmiştir. Gerçekten de günümüz bir gerçeği olarak öğrencileri bilgisayar oyunlarının nasıl hazırlandığı konusunda bilgilendirmek yerinde bir seçimdir. Ancak "Oyun ve Sağlığımız" ünitesinde çocukların sağlam bir psikoloji ve bedene sahip olmasında çok büyük önem taşıyan geleneksel oyunlara dört metinde de yer verilmemesi; sürekli bilgisayar oyunlarından, onun çocuğa verdiği heyecan ve mutluluktan söz edilmesi kabul edilebilir bir tercih değildir. Geleneğin tersine takınılan bir tavır olmuştur.

- Bu ünitede yer alan diğer üç metin de yine bilgisayar oyunları çerçevesinde şekillendirilmiştir.

- Sadece ünitenin kapağında halat çeken 4 çocuk resmi yer almıştır.

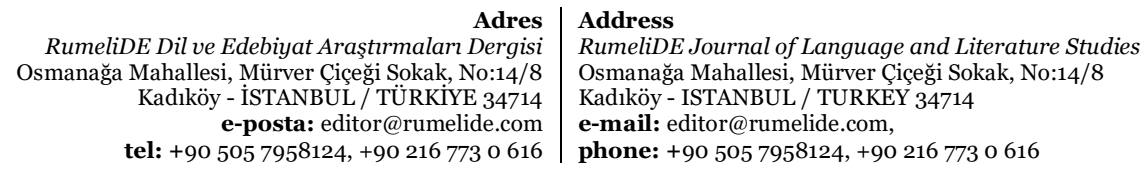

Adres
RumeliDE Dil ve Edebiyat Araştırmaları Dergisi (1) Mürver Çiç Sokak, No:14/8 tel: +90 505 7958124, +902167730616 
- $\quad$ En uygun üniteler olan 4. ve 7. üniteler de dahil olmak üzere, kitabın hiçbir metninde geleneksel oyunlara dair, "oyun adı, oyun terimi, oynayan çocuk resmi veya fotoğrafı" yer almamaktadır.

5. Dördüncü sınıf Türkçe ders kitabı geleneksel oyunlar açısında incelendiğinde şu tespitleri yapmak mümkün olmaktadır:

- Dördüncü sınıf Türkçe ders kitabının, bir oyun anlatımı ve iki oyuncak tanıtımı ile geleneksel oyun açısından en "şanslı kitap" olduğu görülmektedir.

- Türk edebiyatının önemli yazarlarından Adalet Ağaoğlu'nun anı türünde kalem aldığı yazı, oyuncak bir bebek etrafında şekillenmektedir.

- Uçurtma hakkında ayrıntılı bir bilgi verilmiş ve uçurtmanın nasıl yapılacağı anlatılmıştır. Uçurtma uçurmayı özendirici bir üslupla yazılmış başarılı bir yazıdır.

- Oyun ve Arkadaşlık adlı parçada yazar topaç, misket gibi geleneksel bir oyuncak yerine "kaykay"ı tercih etmektedir. "Ertesi gün, kolunun altına kaykayını sıkıştıran Çetin, anneannesinin sözlerini düşünerek asansöre bindi.” Bu cümle sosyal ve ekonomik anlamda özendirici bir duygu ifade etmektedir. Ülke genelinde ne kadar çocuğun kaykaya sahip olduğu gerçeği dikkate alındığında, bu özendirici tavrın yerinde olmadığı değerlendirilmektedir.

- "Hayal Çocuk" adlı metnin görselinde elinde top olan bir çocuk resmi kullanılmıştır. Resimde çocukların ne oynadığı belli olmamaktadır.

- Bayram Anıları adlı metinde "mantar" ile ilgili bir cümle kullanılmıştır. Bu metinde de geleneksel oyunların, bugünün değil geçmiş zamanların bir eğlencesi olduğu hissi uyandırılmaktadır.

- Mevlana ile ilgili metinde çocuk adı anılmayan bir oyun oynamaktadır. Yazar burada da bir oyun veya oyuncuğa atıfta bulunma firsatını kullanmamıştır. "Bu sırada oyun oynamakta olan bir çocuk uzaktan Mevlana’ya oyununu bitirene kadar beklemesini söyledi. Mevlana, çocuğu oyunu bitinceye kadar bekledi. Çocuk, oyunu bitince koşa koşa Mevlana’nın yanına geldi.” Oysa oyuna dair eklenecek bir iki kelime, çocuğun dünyasında güzel bir karşılık bulmaya imkan verebilirdi.

6. Üçüncü sınıf Türkçe ders kitabında ise yapılan inceleme sonucunda aşağıdaki sonuçlara ulaşılmıştır.

- “Oyuncakçı Dede” adlı metinde geçmiş zaman geleneklerine değinilmiş ve çeşitli oyuncak adları verilmiştir. "Bir zamanlar küçük bir şehirde bir oyuncakçı yaşardı. Bembeyaz sakalı pamuk gibiydi. Oyuncak dükkânı açacak kadar parası yoktu. Koluna taktı̆̆ı sepetinde çeşit çeşit oyuncaklar bulundururdu. Bebekleri, arabaları, bilyeleri, çemberleri vardı."

- Oyuna dair atıf ders kitabında sadece "Oyuncakçı Dede" adlı metinde vardır. Çalışma kitabında ise oyuna iki yerde atıfta bulunulmuştur: Dört görsel verilerek çocukların oynadıkları oyunların adlarının yazması istenmiş ve yine bir başka görselde "bir ağaca gözlerini kapatan bir çocuk” resmi verilerek oyunun anlatılması istenmiştir.

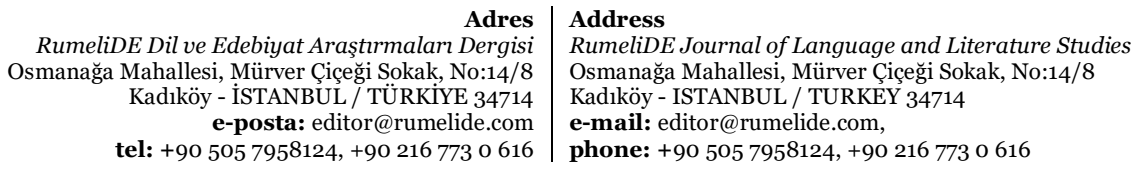




\section{Sonuç / öneriler}

Yapılan bu çalışmayla MEB tarafından okullarda eğitim materyali olarak kullanılan Türkçe ders kitaplarında yer alan metinlerin, çocuk oyunlarının aktarımında ne ölçüde fonksiyonel olduğu belirlenmeye çalışlımıştır.

1. Alıntı yapılacak metin seçimlerinde veya yazarlar tarafından yapılan yazımlarında çocuk oyunlarına kural, terim veya ad bazında atıfta bulunma olanağı varken, bu firsatların kullanılmadığı ilk dikkat çeken önemli bir sonuçtur.

2. Türkçe dersi ders kitapları hazırlanmadan önce çocukların zihin, dil ve sosyal gelişimlerine uygun hangi kültürel unsurun, daha dar alanda çocuk oyunların nasıl verileceği belirlenmeli, daha sonra bir plan çerçevesinde birinci sınıftan sekizinci sınıfa kadar ders kitaplarına yerleştirilmelidir.

3. Oyun çocuğun en ciddi işidir ve çocuk dünyayı oyunla öğrenir. Bu nedenle öğrencileri oyunlarla tanıştırma, oyunlardan haberdar etme, hedef kitlesi oyun oynayan çocuklar olan bir ders kitabının asli görevlerinden olmalıdır.

4. İlkokul Türkçe dersi ders kitaplarında özellikle geleneksel oyunlara özel önem verilmelidir. Çocuğun sosyalleşme ve rahatlama yollarından biri olan oyunlar, bu yaş grubuna metinler üzerinden verilirken, özendirici bir formatta sunulmalıdır. Tarihe mal olmuş, tükenmiş veya kırsala ait bir değer olarak takdim edilmemelidir.

5. Elbette bugünün çocuğunu bilgisayar oyunlarından tamamen koparmak imkansızdır zaten gerekli de değildir. Ancak bedenini kullanarak ve arkadaşlarıyla paylaşıma girerek geleneksel oyunların oynaması çocuğun sağlıklı gelişimi için önemli bir ihtiyaçtır. Bu denge yazarlar tarafından iyi bilinmeli ve korunmalıdır.

6. Bilgisayar oyunlarının esasında yer alan "şiddetin" gerçek yaşamda nelere yol açtı̆̆ı ve bu oyunlara bağımlılığın getireceği aşırı bireyci yaşamın ne sonuçlar vereceği bugünden görülmektedir.

7. Kişisel bir tercih olarak, görsellerin özensizliği dikkat çekmektedir. Oyun denilince ressamların aklına sadece top peşinde koşan çocuklar geldiği görülmektedir. Oyun kavramı iyice daralmış, içi boşalmış durumdadir.

8. MEB tarafından hazırlanan ders programlarının kazanımlar bölümünde kültürel unsurlar genel hatlarıyla belirtilmekte olup, açık bir risk alınarak, ayrıntı yazara bırakılmaktadır. Oysa ki kazanımlar kısmına geleneksel oyunlara dair birtakım net hedefler konması, yazarların bu konuya olan duyarlılıklarını artıracaktır.

9. Tekerleme ve sayışmaların kitaplarda yer alması, çocukların güzel konuşma konusunda yetenek geliştirici çalışma yapmalarına fırsat vermesi yanında, oyun oynarken lazım olan becerileri de elde etmelerine imkan verecektir.

10. Üç sınıfa ait ders kitabında sadece bir metinde uçurtma yapımı ile ilgili bilgi verilmiştir. Bu başarılı metne benzeyen metinlerle çocukların el becerilerini geliştirecek ve onlara ayrı bir haz verecek olan oyuncak yapımına ilişkin metinler de kitaplarda yer almalıdır.

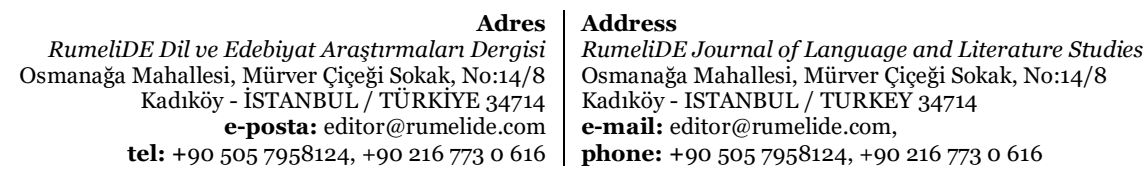


11. Geleneksel oyun modern hayat tarafından dışlanmıştır. Bu kültürün daha çok kırsala ait olduğu ve orada kalması gerektiği genel kabul gören bir durumdur. Örneğin bir metinde geçen arkadaşları ile tanışmak için kaykay oyuncağını paylaşan çocuğun asansöre binmesi, iki temel soruyu akıllara getirmektedir: Türkiye'de kaç çocuğun kaykayı vardır? Bu oyun gereci ile oynanabilecek özel hazırlanmış kaç oyun alanı bulunmaktadır? "Asansörlü ev ve kaykay" aynı cümle içinde verilerek örtülü bir şehirleşme özentisi sağlanmaktadır. Örneğin topaç çevirmek de bu metinde kolaylıkla kullanılabilecek bir oyuncak iken yazar tercihini farklı alanda kullanılmıştır.

Türkçe ders kitaplarının kültürel aktarım fonksiyonları dikkate alındığında, geleneksel oyun açısından çok yetersiz olduğu görülmektedir. Türkçe öğretim programlarında temalardan hareketle aktarılacak kültürel değerler belirlenirken çocuk dünyasında en ciddi iş olan "oyun”, planlı olarak ele alınmalı ve kitaplar oyun bazlı öğretici metinlerle zenginleştirilmelidir. Okul bahçeleri ve parklar, bu oyunların oynanabileceği şekilde dizayn edilmelidir.

\section{Kaynakça}

Aksan, D. /1975) “Anadili”. Türk Dili Dergisi, S. 285. s. 423-433.

Cemiloğlu, M. (2004). Türkçe Öğretimi. İstanbul, Aktüel Yayınevi.

Demircan, C. (2006) Mektepli Gazetesi’nde Yer Alan Metinlerin İçeriğinin Çocukların Bilişsel ve Ahlaki Gelişmelerine Katkısı (1-148. Sayılar), (Yüksek Lisans Tezi, 2006), Mersin Üniversitesi, Sosyal Bilimler Enstitüsü.

MEB. İlköğretim Türkçe Dersi (6-8. Sınıflar) Öğretim Programı ve Kılavuzu. Devlet Kitapları Müdürlüğü. Ankara, 2005.

Oğuzkan, A. Ferhan (2000). Çocuk Edebiyatı. Ankara, Anı Yayıncılık

Özbay, M. (2002). Kültür Aktarımı Açısından Türkçe Öğretimi. Türk Dili, (602), 112-120.

Sever, S. (2006). Türkçe Öğretiminin Sorunlar. Varlık Dergisi, İstanbul, 1189.

Sever, S. (2005). 2004 Öğretim Programında Türkçe Öğretimi Anlayışı. Yeni İlköğretim Programlarını Değerlendirme Sempozyumu 14-16 Kasım 2005, Kayseri, Erciyes Üniversitesi Yayınları 177-192.

Sever, S. (2003). Çocuk ve Edebiyat. Ankara, Kok Yayıncllı.

Adres
RumeliDE Dil ve Edebiyat Araşturmaları Dergisi Osmanağa Mahallesi, Mürver Çiçeği Sokak, No:14/8 Kadıköy - İSTANBUL / TÜRKIYE 34714 e-posta: editor@rumelide.com tel: +90 $5057958124,+902167730616$
Address

RumeliDE Journal of Language and Literature Studies

Osmanağa Mahallesi, Mürver Çiçeği Sokak, No:14/8

Kadıköy - ISTANBUL / TURKEY 34714

e-mail: editor@rumelide.com

phone: +90 5057958124, +90 2167730616 